\title{
COMPARATIVE ANALYSIS OF LABOR MARKET TRANSFORMATION IN UKRAINE AND THE USA UNDER CONDITION OF BALANCED REGIONAL DEVELOPMENT
}

\section{Khovrak, D. Solodkov}

Kremenchuk Mykhailo Ostrohradskyi National University

vul. Pershotravneva, 20, Kremenchuk, 39600, Ukraine. E-mail: inna.khovrak.w@ gmail.com

Purpose. The article highlights the issue of readiness of workforce in Ukraine and the USA for permanent and rapid transformation of the labor market, taking into account the need to ensure balanced regional development. Although the issue is considered to be relevant both for developing economies and developed ones, it is not yet known whether workforce of both kinds of economies is equally prepared for the changes occurring. At the same time, one of the main sources of balanced regional development is the attractiveness of the region for residents and the level of development of the regional labor market. Methodology. In order to undertake comprehensive comparative research, the authors conducted the survey among different categories of Ukrainians and Americans according to their gender, age, profession type, size of their settlements. In total, more than two hundred respondents participated in the survey, more than one hundred from each country. Results. The authors found that Ukrainians, in comparison with Americans, are better prepared for the changes in the labor market that occur as a result of the replacement of human labor by machine, the change in the structure of the world and national economies and other factors. At the same time, citizens aged 25-40 are most prepared for transformation in both countries. Originality. The authors calculated the Adaptation Index, which reflects the level of readiness for transformation of the labor market and the higher the index, the greater the level of ability to adapt. The index ranges from 0 to 10 and takes into account the answers to the questions about the degree of creativity in the work, the quality of education, the importance of education to get the desired job, the impact of computerization, the importance of gaining additional skills and knowledge, the prospects of remote work. Practical value. Because understanding the trends emerging in the national or even global economy make it possible to anticipate changes at regional and sectoral levels, the article provides an analysis of respondents' views on labor market transformation over the next 10 years.

Key words: workforce, transformation, Ukraine, the USA, survey, adaption, index.

\section{КОМПАРАТИВНИЙ АНАЛІЗ ТРАНСФОРМАЦЇ РИНКУ ПРАЦІ В УКРАЇНІ ТА США В УМОВАХ ЗАБЕЗПЕЧЕННЯ ЗБАЛАНСОВАНОГО РЕГІОНАЛЬНОГО РОЗВИТКУ}

\section{І. В. Ховрак, Д. С. Солодков}

Кременчуцький національний університет імені Михайла Остроградського

вул. Першотравнева, 20, м. Кременчук, 39600, Україна. E-mail: inna.khovrak.w@gmail.com

Робота присвячена питанню готовності трудових ресурсів в Україні та США до постійної й швидкоплинної трансформації ринку праці, враховуючи необхідність забезпечення збалансованого регіонального розвитку. Незважаючи на те, що проблема вважається релевантною як для розвинених, так і для країн, що розвиваються, точно не відомо, в яких мірах трудові ресурси обох типів країн, зокрема України та США, готові до трансформації ринку праці. У той же час одним із головних джерел збалансованого регіонального розвитку є привабливість регіону для жителів та рівень розвитку регіонального ринку праці. 3 метою здійснення комплексного компаративного дослідження автори провели опитування серед різних категорій українців і американців: відносно статі, віку, типу професії, розміру поселення. Загалом, більше двохсот респондентів взяло участь в опитування, понад сто з кожної країни. Виявлено, що українці, у порівнянні з американцями, трохи краще підготовлені до змін на ринку праці, що відбуваються внаслідок заміни людської праці на машинну, зміну структури світової та національних економік та інших факторів. При цьому, громадяни віком 25-40 років $є$ найбільш підготовленими до трансформації в обох країнах. Авторами розраховано індекс адаптивності, який відображає рівень готовності до трансформації ринку праці, і чим вище показник, тим більший рівень здатності адаптуватись. Індекс знаходиться в межах від 0 до 10 та враховує відповіді на запитання про ступінь творчості в роботі, якість освіти, важливість освіти для отримання бажаної роботи, вплив комп'ютеризації, важливість здобуття додаткових навичок та знань, перспективи віддаленої роботи. Загальні бали за країнами містять усереднені дані за категоріями статі, віку, професії та категорій поселень. Значення індексу: Україна 6,18, США 6,06. Встановлено, що основними компетенціями, на думку респондентів з України, є розв'язування складних завдань, оцінка та прийняття рішень, планування. Однак, на думку респондентів з США, основними компетенціями є розв'язування складних завдань, когнітивна гнучкість, оцінка та прийняття рішень. Оскільки розуміння тенденцій, що виникають у масштабах національної чи навіть глобальної економіки, дозволяють передбачити зміни на регіональному та галузевому рівнях, стаття містить аналіз думок респондентів щодо трансформації ринку праці на наступні 10 років.

Ключові слова: трудові ресурси, трансформація, Україна, США, опитування, адаптація, індекс.

PROBLEM STATEMENT. At present, balanced regional development is the key to many countries' development. At the same time, one of the main sources of balanced regional development is the attractiveness of the region for residents and the level of development of the regional labor market. Foreign researchers pay considerable attention to the study of regional labor markets, the causes of market crises and possible tools for improving the situation. A large amount of research devoted to finding the source of regional labor market 
development. The authors believe that such a source is the development of certain sectors of the economy or the establishment of efficient enterprises in the region.For example, casinos $[1 ; 2]$, large retail stores [3; 4], large manufacturing plants [5; 6], professional sports facilities $[7 ; 8]$, and major events such as the Olympics $[9 ; 10]$ may be the main initiators of regional labor market development. Scientists also argue for a significant impact of international shocks on employment and wages [11-15]. As a result, significant resources are spent annually from the state, regional and local budgets to solve the problems of regional labor markets [16]. However, regulatory and financial instruments are insufficient to strengthen regional labor markets. Accordingly, regional development is achieved on the basis of a combination of different stakeholders, such as regional authorities, universities, enterprises[17-19].For balanced regional development and their labor markets, a prerequisite is the desire of citizens to live, develop and work in the region. Citizens should be interested in changing global, national and regional markets, paying attention to self-development and lifelong learning. It is important to understand that achieving balanced regional development improves the quality of life of residents and improves the attractiveness of the region [20].

Due to significant changes that occur in global labor market due to globalization, automation and other processes, the question of how to keep being competitive is getting more relevant. Considering that the issue affects economies and, therefore, labor markets of both developing and developed countries, it is important to track down the differences between the readiness to labor market transformation and activity of workforce in Ukraine (as developing) and, for comparison, in the USA (as developed one). Besides, the way the workforce of both countries perceives some social issues which may be potentially caused by globalization and automation (predominantly), may deeply correlate with its readiness and activity, especially in long terms. Thus, the problem requires a comprehensive comparative research of workforce's perspectives by a survey among people aged 15-65 (labor force) from Ukraine and the USA.

The issue of labor market transformation due to automation is already well-studied by numerous institu- tions and HR organizations, such as BCG, International Social Security Organization. Besides, the readiness of workforce to the challenges potentially caused by Industry 4.0 was explored by SIOP, Council of the EU [21] and World Economic Forum in terms of competences' demand [22]. All the studies done mostly consider the issue's influence in developed countries, whereas there is lack of research done on the problem impact on developing economies, particularly on Ukrainian labor market.

The aim of the study is a comparative analysis of the activity degree and rates of readiness to labor market transformation of Ukrainian and American workforce divided into different categories. In order to attain the objective, it is necessary to solve the following tasks, relying on the participants' answers:

to determine the share of active workforce in each category;

- $\quad$ to calculate the Adaptation Index;

- $\quad$ to analyze the rate of currently important competencies and those which might be important in the nearest future;

- to define workforce perspectives of an automation influence on the labor market.

MATERIAL AND RESULTS.The article consists of four parts, namely Portfolio, Adaptation Index, Competencies rate, Macro Scale Perspective. The findings of the study were based on information gathered through an online survey of more than 200 respondents from Ukraine and the USA.

Part I. Portfolio. In this part an activity of Ukrainian and US respondents as workforce was studied. The objective of this section is to get a general image of distinctions between Ukraine's and the US's labor markets' conditions which partially express in activity of labor resources.

Among the most expository indicators of workforce market conditions are employment rate (Fig. 1) and professional education applicability on labor market (Fig. 2) that were studied among various categories of respondents. The common trends for both of countries are a comparatively high unemployment rate among youth and the lowest among respondents aged 25-40 y. o.

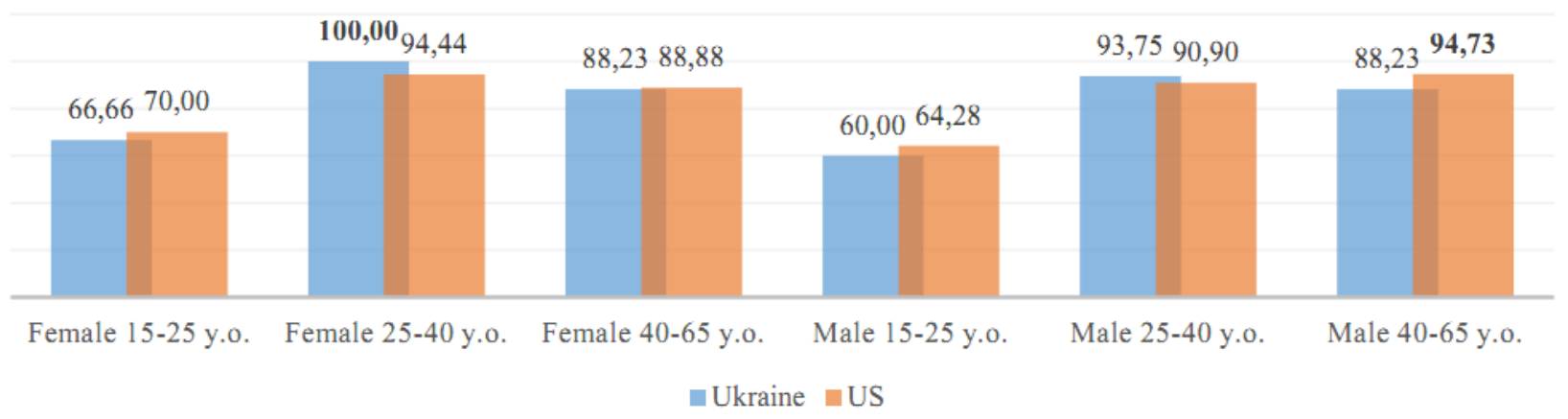

Figure 1 - Percentage of respondents that have worked for the last 12 months, $\%$ 


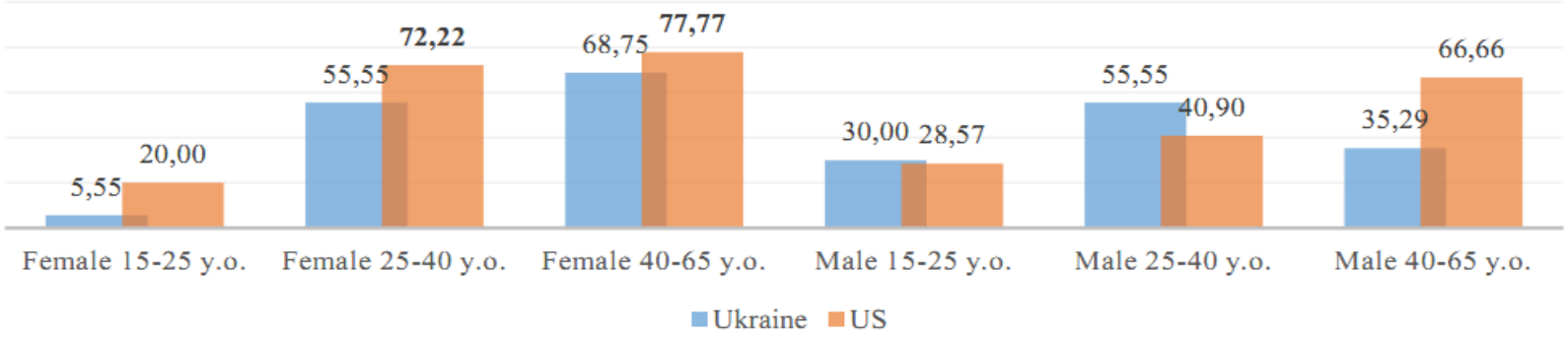

Figure 2- Percentage of respondents successfully applied (planning to apply) their professional education on workforce market, $\%$

A relatively high diploma applicability can be distinguished among female American and Ukrainian respondents of 25-60 y. o., whereas, among majority, it is average or lower than that and naturally low among the youngest participants.

Amid the factors that increase a probability of successful placement is an awareness of workforce market supply and demand. To find a correlation between employment rate, diploma applicability and the factor of awareness, the percentage of labor market research before gaining a professional education (Fig. 3) and the general frequency of it (Table 1) were determined. Amidst the trends revealed there are: a rise of market research done among US participants of both genders from the most mature to the youngest ones, higher rates of research undertaking among males of both origins, prevailing of UA over US, excepting in the youngest part of the sample.

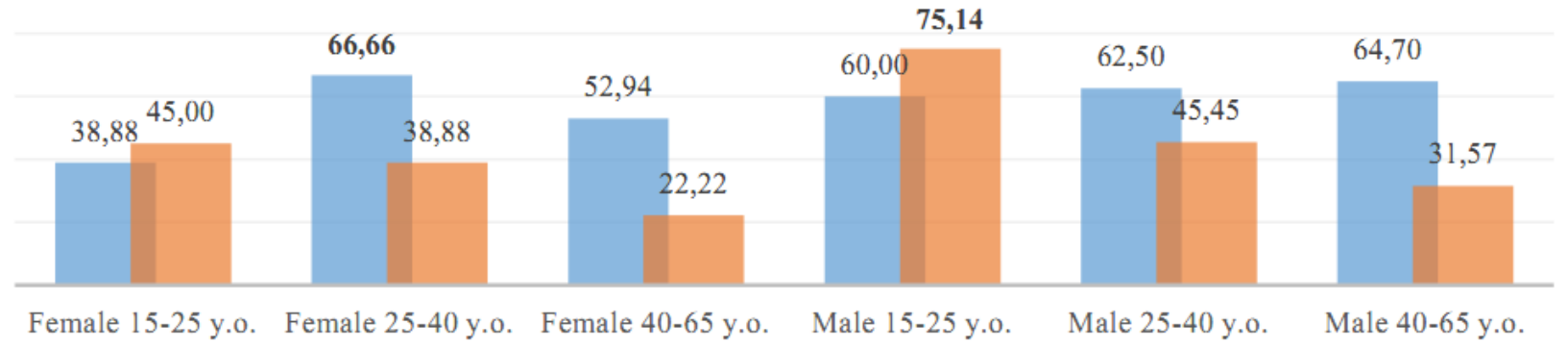

ukraine uS

Figure 3- Percentage of labor market research done before getting prof. education, $\%$

Table 1-Comparison of the frequency of labor market research Ukrainian and American respondents undertake, \%

\begin{tabular}{|l|c|c|c|c|c|c|}
\hline \multirow{3}{*}{ Response options for respondents } & \multicolumn{3}{|c|}{ Age } \\
\cline { 2 - 7 } & \multicolumn{3}{|c|}{ Ukraine } & \multicolumn{4}{c|}{ the USA } \\
\cline { 2 - 7 } & $15-25$ & $25-40$ & $40-65$ & $15-25$ & $25-40$ & $40-65$ \\
\hline Never & $\mathbf{1 2 , 1 4}$ & $\mathbf{1 0 , 2 8}$ & 8,41 & 1,96 & 5,88 & 6,86 \\
\hline Once a year & 10,28 & $\mathbf{1 0 , 2 8}$ & 8,41 & $\mathbf{1 4 , 7 0}$ & $\mathbf{1 7 , 6 4}$ & $\mathbf{1 2 , 7 4}$ \\
\hline Once a month & 7,47 & 6,54 & $\mathbf{1 0 , 2 8}$ & 8,82 & 8,82 & 4,90 \\
\hline Once a week & 2,80 & 3,73 & 2,80 & 3,92 & 5,88 & 2,94 \\
\hline Several times a week & 2,80 & 0,93 & 2,80 & 3,92 & 0,98 & 0,00 \\
\hline
\end{tabular}

The share of a frequency lower than once a month of research done comprises over a half of all answers both by US and Ukrainian participants. Besides, among Ukrainians the most common is to not undertake the research at all (a third part of answers), whereas most of Americans prefer to look for opportunities once a year.

Comparing the last two data sets, we may distinguish a comparatively higher rate of labor market research done before professional education amid Ukrainians but a higher frequency of the research among Americans. Although, the factor of awareness does not correspond neither with employment rate, nor with diploma applicability that much within the sample.

Another factors that may assumingly affect the employment rate and especially the diploma applicability are perspectives on how frequently it is necessary to change a profession (Table 2) and how important it is to gain new professional skills (Table 3) in order to keep being competitive on the labor market.

A pattern to be emphasized is a comparatively high rate of professional education applied amid 40-65 у. o. respondents of both origins and their attitude to the frequency of profession change - a single for a whole life. This may lead to conclusion that it either was easier to get a permanent placement in previous decades (which is more likely), or it is still a good employment strategy.

A common correlation amidst Ukrainian respondents is the ratio of the employment rates and the share of those who were gaining skills at the moment they have 
submitted the answers: the highest share and the rate amid participants aged 25-40 y. o. as well as the average shares and rates among the 15-25 y. o. and 40-65 y. o.
This might be explained as a requirement of employers, e. g. continuing education courses.

Table 2- Attitude to the frequency of changing profession, $\%$

\begin{tabular}{|l|c|c|c|c|c|c|}
\hline \multirow{3}{*}{ Response options for respondents } & \multicolumn{6}{|c|}{ Age } \\
\cline { 2 - 7 } & \multicolumn{3}{|c|}{ Ukraine } & \multicolumn{3}{c|}{ the USA } \\
\cline { 2 - 7 } & $15-25$ & $25-40$ & $40-65$ & $15-25$ & $25-40$ & $40-65$ \\
\hline Every 5-7 years & $\mathbf{1 9 , 6 2}$ & $\mathbf{1 1 , 2 1}$ & 5,60 & $\mathbf{1 2 , 7 4}$ & $\mathbf{1 9 , 6 0}$ & 3,92 \\
\hline Every 7-10 years & 7,47 & 8,41 & 7,47 & 4,90 & 9,80 & 4,90 \\
\hline Every 10-20 years & 1,86 & 9,34 & 9,34 & 9,80 & 4,90 & 6,86 \\
\hline One prof. for life & 6,54 & 2,80 & $\mathbf{1 0 , 2 8}$ & 5,88 & 4,90 & $\mathbf{1 1 , 7 6}$ \\
\hline
\end{tabular}

Table 3-Attitude to the gaining of new professional skills, \%

\begin{tabular}{|l|c|c|c|c|c|c|}
\hline \multirow{2}{*}{ Response options for respondents } & \multicolumn{3}{|c|}{ Age } \\
\cline { 2 - 7 } & \multicolumn{3}{|c|}{ Ukraine } & \multicolumn{4}{c|}{ the USA } \\
\cline { 2 - 7 } & $15-25$ & $25-40$ & $40-65$ & $15-25$ & $25-40$ & $40-65$ \\
\hline Important, not ready & 4,67 & 3,73 & 7,47 & 8,82 & 10,78 & 8,82 \\
\hline Not important & 0,93 & 7,47 & 4,67 & 0,98 & 0,00 & 2,94 \\
\hline Going to gain & 23,36 & 13,08 & 14,01 & 13,72 & 21,56 & 12,74 \\
\hline Currently gaining & 6,54 & $\mathbf{7 , 4 7}$ & 6,54 & $\mathbf{9 , 8 0}$ & 6,86 & 2,94 \\
\hline
\end{tabular}

Prevailing of males over females in both countries and Ukrainian over US participants in each gender group can be distinguished according to the total scores. Comparing the age groups, it occurs that the most active part of workforce are the people aged 25-40 y. o., and, excepting the youth, Ukrainians surpass US participants in mature age groups. General scores for countries indicates a slightly higher rate of activity of Ukrainian workforce, but average of both of countries comparing to maximum score of 1800 . The crucial factors that determine the results received are comparatively high unemployment rate amid youth, low than in average rates of professional education applicability and labor market research undertaking among a half of respondents of Ukraine and the US.

Part 2. Adaptation Index. This part includes the response' analysis of the questions which required to assess different perspectives connected with education, personal work experience and views on labor market on the grading scale from 0 to 10 (Table 4 ).

Table 4-Comparing of the adaptation rates among the categories

\begin{tabular}{|c|c|c|c|c|c|c|c|c|c|c|c|}
\hline \multicolumn{12}{|c|}{ Gender + Age Category } \\
\hline \multicolumn{6}{|c|}{ Ukraine } & \multicolumn{6}{|c|}{ the USA } \\
\hline \multicolumn{3}{|c|}{ Female } & \multicolumn{3}{|c|}{ Male } & \multicolumn{3}{|c|}{ Female } & \multicolumn{3}{|c|}{ Male } \\
\hline $15-25$ & $25-40$ & $40-65$ & $15-25$ & $25-40$ & $40-65$ & $15-25$ & $25-40$ & $40-65$ & $15-25$ & $25-40$ & $40-65$ \\
\hline 6,52 & 6,54 & 6,81 & 6,68 & 5,93 & 5,63 & 6,25 & 6,37 & 5,60 & 6,60 & 6,75 & 5,50 \\
\hline \multicolumn{12}{|c|}{ Gender Category } \\
\hline \multicolumn{3}{|c|}{ Female } & \multicolumn{3}{|c|}{ Male } & \multicolumn{3}{|c|}{ Female } & \multicolumn{3}{|c|}{ Male } \\
\hline \multicolumn{3}{|c|}{6,62} & \multicolumn{3}{|c|}{6,08} & \multicolumn{3}{|c|}{6,07} & \multicolumn{3}{|c|}{6,28} \\
\hline \multicolumn{12}{|c|}{ Age Category } \\
\hline & & \multicolumn{2}{|c|}{$25-40$} & \multicolumn{2}{|c|}{$40-65$} & \multicolumn{2}{|c|}{$15-25$} & \multicolumn{2}{|c|}{$25-40$} & \multicolumn{2}{|c|}{$40-65$} \\
\hline & & \multicolumn{2}{|c|}{6,23} & \multicolumn{2}{|c|}{6,22} & \multicolumn{2}{|c|}{6,42} & \multicolumn{2}{|c|}{6,56} & \multicolumn{2}{|c|}{5,55} \\
\hline \multicolumn{12}{|c|}{ Profession Type Category } \\
\hline \multicolumn{6}{|c|}{ Ukraine } & \multicolumn{6}{|c|}{ the USA } \\
\hline \multicolumn{2}{|c|}{ General skills } & \multicolumn{2}{|c|}{ Professional } & $\mathrm{Kno}$ & ledge & Gener & I skills & Profe & sional & Kno & ledge \\
\hline & & & & & 39 & & & & 37 & & 36 \\
\hline & & & & & tlement & ze Categ & & & & & \\
\hline & & & aine & & & & & the & JSA & & \\
\hline & age & & & $\mathrm{Me}$ & polis & & age & & ty & Met & polis \\
\hline & & & 56 & & 23 & & & & 27 & & 54 \\
\hline & & & Com & ng of $t$ & Total S & res of the & Adaptati & Index & & & \\
\hline & & & aine & & & & & the & JSA & & \\
\hline & & & & & & & & & 06 & & \\
\hline
\end{tabular}

The index anticipates readiness rate of the categories to adapt to labor market transformation, and the higher rate is, the more a certain category is ready. Among the categories, there are: according to gender, age, profes- sion type, and settlement size. The data presented are the average values of answers for questions about the degree of creativity for work, the quality of education, the importance of education for getting a dream job, 
positive influence computerization, the importance of gaining additional skills and knowledge, the prospect of remote (online) work. The total scores for the countries comprise averaged data from Gender, Age, Profession type and settlement categories.

According to the values gotten, the vast majority of answers lies in the middle of the scale, which may indicate a lack of clarity in the attitude to a degree of such matters as work creativity, professional training quality and applicability, computerization influence, remote work and necessity of gaining additional skills. Comparatively clear perspective of the matters belongs to UA and US respondents with profession type of 'Knowledge'. In general, there is a sustainable trend of inessential prevailing of Ukrainian participants over American in terms of score rate, and the total score is slightly higher for Ukraine as well. Nevertheless, there is no significant distinctions between two national groups studied in the Adaptation Index.

Part 3. Competencies rate. In order to adapt to the constantly changing workforce environment, it is crucial to obtain skills that would allow to be in demand as for employees, and competitive as for entrepreneurs. There are numerous abilities considered to be important by European Commission [21], Economic World Forum [22] etc. The 14 most common and important from the authors' perspectives competencies were chosen (Table 5), represented in the survey and then analyzed.

Table 5-Competencies Rate(MultipleChoice-Maximum 3 Answers), \%

\begin{tabular}{|l|c|c|c|c|}
\hline \multirow{2}{*}{ Competency } & \multicolumn{2}{c|}{ Ukraine } & \multicolumn{2}{c|}{ the USA } \\
\cline { 2 - 5 } & For now & In 5 years & For now & years \\
\hline Solving of Difficult Tasks & $\mathbf{5 5 , 1}$ & $\mathbf{8 8 , 2}$ & $\mathbf{4 7 , 1}$ & $\mathbf{3 9 , 2}$ \\
\hline Quality Control & 44,9 & $\mathbf{7 0 , 6}$ & 12,7 & 8,8 \\
\hline Active Listening & 37,4 & 51,0 & 27,5 & 25,5 \\
\hline Negotiation & 35,5 & 49,0 & 24,5 & 21,6 \\
\hline Psychological / Physical Self- & 26,2 & 60,8 & 10,8 & 11,8 \\
Defense & & & & \\
\hline Cognitive Flexibility & 31,8 & 41,2 & $\mathbf{3 2 , 4}$ & 26,5 \\
\hline Assessing And Decision Making & $\mathbf{4 6 , 7}$ & 51,0 & $\mathbf{3 0 , 4}$ & $\mathbf{2 7 , 5}$ \\
\hline Leadership and Management & 36,4 & 41,2 & 20,6 & 25,5 \\
\hline Interaction With Others & 34,6 & 45,1 & 25,5 & 19,6 \\
\hline Emotional Intelligence & 32,7 & 43,1 & 15,7 & 14,7 \\
\hline Creativity & 39,3 & 52,9 & 17,6 & 26,5 \\
\hline Critical Thinking & 39,3 & 49,0 & 26,5 & $\mathbf{3 9 , 2}$ \\
\hline Service Orientation & 20,6 & 37,3 & 4,9 & 19,6 \\
\hline Planning & $\mathbf{4 6 , 7}$ & $\mathbf{6 8 , 6}$ & 12,7 & 4,9 \\
\hline
\end{tabular}

Amidst the patterns that can be distinguished, there are Solving of Difficult Tasks as the most frequently chosen competency among the majority of UA and US respondents as a currently and potentially most important one. This might be explained by the fact that the most demanded jobs now lie in the technic and mechanic spheres which usually implies a search of solutions for complex issues. Also, the Assessing and Decision Making was the second most popular response which can be explained by a high need of having this ability for developing efficient business, marketing, management and finance policies.

Besides, there were competencies commonly chosen by only one national group, for instance, Cognitive flexibility as currently important and Critical Thinking in 5-year perspective which were selected by Americans, and Quality Control, counted to be important in 5 years, as well as Planning, considered to be relevant both for now and in 5 years selected by Ukrainians. The specific tendencies of choice made by UA participants can probably be explained by ways planning and quality control were and are still perceived since the USSR when those principles were taken as the most important ones.

Part 4. Macro Scale Perspective. Besides personal interest of labor market opportunities, it is important to grasp tendencies occur in scales of national or even global economy in order to better anticipate the changes on regional and industrial levels. In order to determine the way Ukrainian and American workforce perceives those tendencies, the questions on automation macro influence were included (table 6).

Generally positive views amid both UA and US respondents on the labor market transformation happened during previous decade can be observed. Almost the opposite position can be distinguished in the anticipation for the next 10 years, where Americans expect most of manual and intellectual human labor will be replaced with machinery, whereas Ukrainians consider no major changes.

Quite controversial are the results of perspective of public administration automation, where most of US participants would like this sphere to be automated and among Ukrainian respondents the majority was either not sure, or unlikely they would like this to happen. This is an interesting ratio considering the effectiveness of public spheres in the United States and Ukraine.

According to basic income imposing part, the half of UA and US respondents were not sure about the probability of this initiative, and the same share would vote for. Still, over a half of American and Ukrainian participants doubted the implications of wide spread of basic income in society. In general, there are more common trends in perception of the issues considered in this part than distinctions among the national groups. 
Table 6-Comparing of survey results in part Macro Scale Perspective, \%

Perspective of labor market transformation for the last 10 years

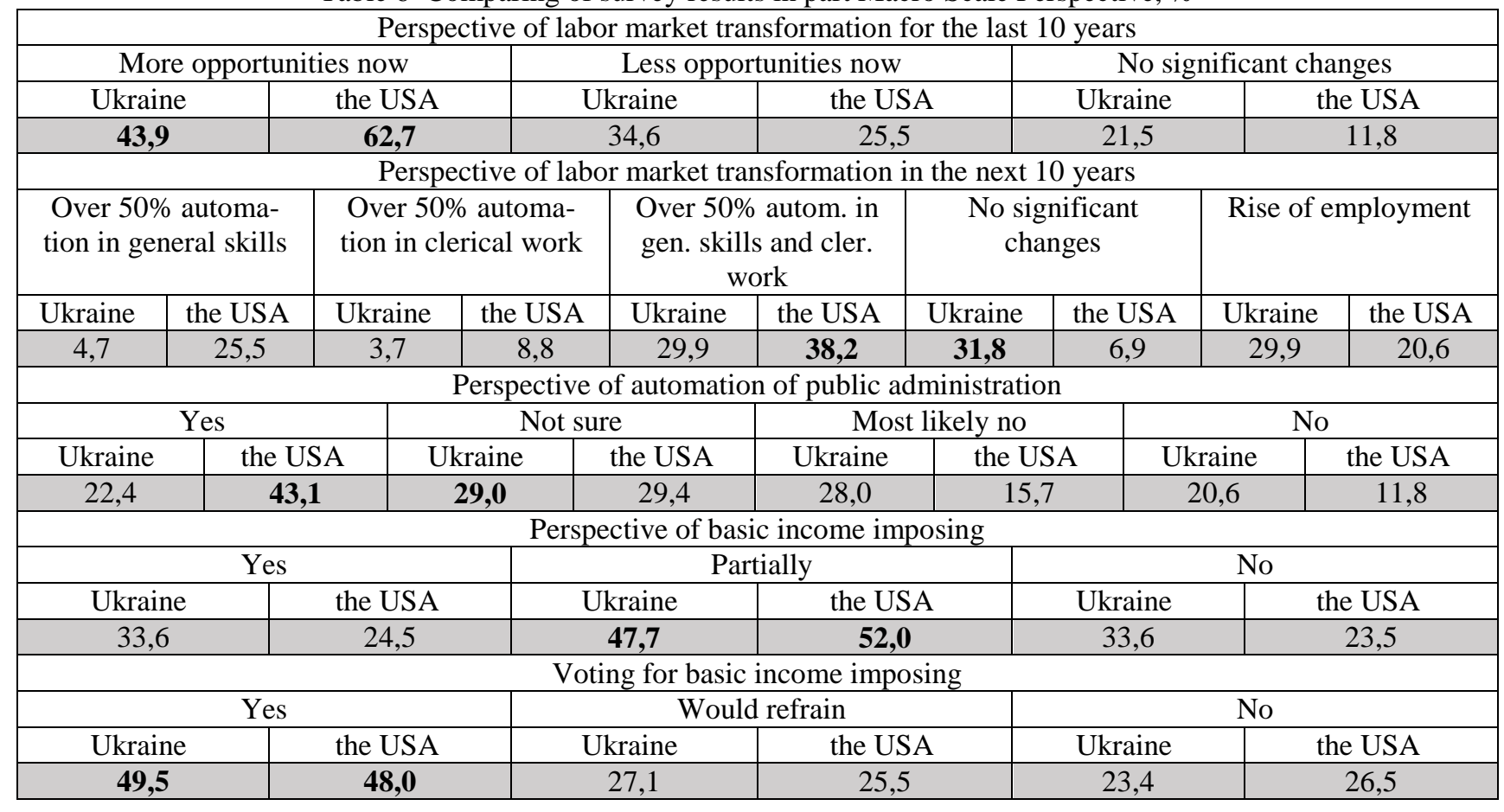

CONCLUSIONS. Such phenomena as globalization and automation bring about significant changes to national economies, specifically to life quality, labor market opportunities, level of incomes, social security and other matters that are far important to employees. As the new opportunities appear, the others are shrinking, so workforce in most of countries is ought to be agile to the new ratios of supply and demand, which means to react in time to those changes in order not to be thrown out of labor market. According to the results of the survey and their analysis, the further claims can be expressed:

1) There is no significant differences between the Ukrainian and American respondents in terms of their activity as workforce and their readiness to the transformation of labor market. Besides, it can be also applied to the way UA and US respondents perceive most of issues considered in this study. This indicates a high degree of integration of the workforce in global scales which positively affects its mobility.

2) In order to be competitive in long-term perspective, it is necessary to obtain most demanded competencies which are solving of complex tasks, assessing and decision making and critical thinking. These abilities will assumingly be in demand not only in frames of national, but also a global economy. Besides, it is important to regularly observe labor market demand, even being already employed. This may help to navigate in regard of what new skills to gain or even a new profession to take, which as well might be relevant in long terms.

3) To deepen into the issue, the further research is ought to be undertaken: to width the sample up to a thousand respondents; include employers and HR specialists as a separate category with a different questionnaire from the perspective of labor market demand; to conduct the survey among other nations, preferably from Asian countries as the fastest growing economies.

\section{REFERENCES}

1. Cotti, C. (2008), The effect of casinos on local labor markets: A county level analysis, Journal of Gambling Business and Economics, no. 2(2), pp. 17-41.

2. Humphreys, B., Marchand, J. (2013), New casinos and local labor markets: Evidence from Canada, Labour Economics, no. 24, pp. 151-160.

3. Basker, E. (2005), Job creation or destruction? Labor market effects of Wal-Mart expansion, Review of Economics and Statistics, no. 87(1), pp. 174-183.

4. Neumark, D., Zhang, J., Ciccarella, S. (2008), The effects of Wal-Mart on local labor markets, Journal of Urban Economics, no. 63(2), pp. 405-430.

5. Greenstone, M., Hornbeck, R., Moretti, E. (2010), Identifying agglomeration spillovers: Evidence from winners and losers of large plant openings, Journal of Political Economy, no. 118(3), pp. 536-598.

6. Adams, B. (2016), The employment impact of motor vehicle assembly plant openings, Regional Science and Urban Economics, no. 58, pp. 57-70.

7. Coates, D., Humphreys, B. (2003), The effect of professional sports on earnings and employment in the services and retail sectors in US cities, Regional Science and Urban Economics, no. 33(2), pp. 175-198.

8. Siegfried, J., Zimbalist, A. (2000), The economics of sports facilities and their communities, Journal of Economic Perspectives, no. 14(3), pp. 95-114.

9. Billings, S., Holladay, S. (2012), Should cities go for the gold? The long-term impacts of hosting the Olympics, Economic Inquiry, no. 50(3), pp. 754-772.

10. Baade, R., Matheson, V. (2016), Going for the gold: The economics of the Olympics, Journal of Economic Perspectives, no. 30(2), pp. 201-18.

11. Autor, D., Dorn, D., Hanson, G. H. (2013), The china syndrome: Local labor market effects of import competition in the united states, The American Economic Review, no. 103 (6), pp. 2121-2168. 
12. Autor, D. H., Dorn, D., Hanson, G. H., Song, J. (2014), Trade adjustment: Worker-level evidence, The Quarterly Journal of Economics, no. 129 (4), pp. 17991860.

13. Kovak, B. K. (2013), Regional effects of trade reform: What is the correct measure of liberalization? The American Economic Review, no. 103 (5), pp. 19601976.

14. Pierce, J. R., Schott, P. K. (2016), The surprisingly swift decline of us manufacturing employment, The American Economic Review, no. 106 (7), pp. 16321662.

15. Topalova, P. (2010), Factor immobility and regional impacts of trade liberalization: Evidence on poverty from India, American Economic Journal: Applied Economics, no. 2 (4), pp. 1-41.

16. Bartik, T. J. (2004), Economic development, Management Policies in Local Government Finance, ed. J. Richard Aronson and Eli Schwartz.

17. Buzko, I., Vartanova, O., Trunina, I., Khovrak, I. (2019), Theoretical aspects of regional sustainable de- velopment in the EU and Ukraine, Innovative Economic Symposium 2018, SHS Web of Conferences 61, pp. 01001.

18. Trunina, I., Khovrak, I., Sushchenko, S. (2019), Big Data in sustainable regional development: the digital future of smart regions, International Journal of $3 D$ Printing Technologies and Digital Industry, no. 3 (2), pp. 116-123.

19. Trynchuk, V., Khovrak, I. (2019), The role of universities in disseminating the social responsibility practices of insurance companies, Problems and Perspectives in Management, no. 17(2), pp. 449-461.

20. Khovrak, I. (2019), Evolution of regional development paradigm, Modern Economics, no. 13, pp. 246252.

21. European key competences for lifelong learning: outcome of the Council Meeting (2018), Council of the European Union, $22 \mathrm{p}$.

22. The Future of Jobs Report 2018: Centre for the New Economy and Society (2018), World Economic Forum, $147 \mathrm{p}$.

\section{КОМПАРАТИВНЫЙ АНАЛИЗ ТРАНСФОРМАЦИИ РЫНКА ТРУДА В УКРАИНЕ И США В УСЛОВИЯХ ОБЕСПЕЧЕНИЯ СБАЛАНСИРОВАННОГО РЕГИОНАЛЬНОГО РАЗВИТИЯ}

\section{И. В. Ховрак, Д. Е. Солодков}

Кременчугский национальный университет имени Михаила Остроградского

ул. Первомайская, 20, г. Кременчуг, 39600, Украина. E-mail: inna.khovrak.w@gmail.com

Статья посвящена вопросу готовности трудовых ресурсов в Украине и США к постоянной и скоротечной трансформации рынка труда, учитывая необходимость обеспечения сбалансированного регионального развития. Несмотря на то, что проблема считается релевантной как для развитых, так и для развивающихся стран, точно не известно, в каких мерах трудовые ресурсы обоих типов стран, в частности Украины и США, готовы к трансформации рынка труда. С целью осуществления комплексного сравнительного исследования авторы провели опрос среди разных категорий жителей Украины и США: относительно пола, возраста, типа профессии, размера поселения. В общем, более двухсот респондентов приняли участие в опросе, более ста из каждой страны. Статья состоит из четырех частей: портфолио, индекс адаптивности, уровень компетенций, макроперспектива. Авторы установили, что украинцы, по сравнению с американцами, немного лучше подготовлены к изменениям на рынке труда, происходящих вследствие замены человеческого труда на машинный, изменения структуры мировой и национальных экономик, а также других факторов. Кроме этого, в процессе сравнения разных возрастных категорий установлено, что наиболее подготовленными к трансформации оказались жители в возрасте 25-40 лет, что характерно для обеих стран.

Ключевые слова: трудовые ресурсы, трансформация, Украина, США, опрос, адаптация, индекс. 